Check for updates

London, UK

Cite this as: BMJ 2021;374:n1935 http://dx.doi.org/10.1136/bmi.n1935 Published: 02 August 2021

\section{Covid 19: Most patients in England received good or excellent care in hospital, finds analysis}

\author{
Adrian O’Dowd
}

Most patients admitted to hospitals in England with SARS-CoV-2 in 2020 received good care despite the challenges of dealing with a new disease, according to a review produced by the Royal College of Physicians (RCP). ${ }^{1}$

For the study, which the college described as the largest to date of care given to covid-19 patients in the country, the authors gathered information on the quality of care delivered by 19 NHS trusts which accounted for a population of almost 10.5 million people exposed to the virus.

The organisations looked after 26326 cases of covid-19 in 2020. Of those, 6389 (24.2\%) died with the condition while in their care. Some 510 patient care records were reviewed, of which 425 were individually identifiable.

A modified version of an established structured judgment review process was used to analyse acute hospital deaths. It found that overall care delivered was judged to have been "adequate," "good," or “excellent” for $96.5 \%$ of patients. ("Good” or “excellent” care was found for $77.4 \%$ of cases.)

In contrast, only $3.5 \%$ of the cases involved care judged to be "poor" which was related to end-of-life care, infections acquired in hospital, assessment delays, and poor communication and poor documentation. None of these cases affected the outcomes for the patients, said the report.

The authors also looked at significant variations between hospitals when it came to end-of-life care experiences, assessment, documentation and communication, senior review, do not attempt resuscitation decisions and discharge planning-all of which revealed there had been excellent care as well as care that could have been improved.

Various lessons could be learnt from the report, said the college. It recommended that those hospitals and teams that have delivered excellent care during the pandemic should analyse and publicise the factors that helped them achieve this. In addition, NHS organisations and their staff should strive to reduce variation in care in key areas including end-of-life care in hospital, early assessment, documentation and communication, senior review and decision making, and discharge planning.

The college also called for particular attention to be paid to quality of care, decision making, and communication and documentation required for vulnerable people. There should be further analysis carried out of the variation in the number of deaths from covid-19 between different parts of the country, which ranged from $12 \%$ to $35 \%$ between organisations.
John Dean, the college's clinical director for quality improvement and patient safety, said, "My colleagues in the NHS have been faced with unprecedented challenges during the pandemic but this study shows how almost all care provided has been of the right standard.

"We can, however, learn from excellent care, and variations in care, just as we can learn from poor care. I am sure that this study will prove invaluable as we seek to learn from this extraordinary time."

Susie Orme, consultant in care of the elderly and associate medical director (mortality) at Barnsley Hospital NHS Foundation Trust, which took part in the study, said, "At the start of the first wave of covid-19, before we had the knowledge and the treatments we now have and when at times the only available treatment was to care, we continued to care well.

"This report highlights how healthcare organisations maintained the high standards we would expect in non-pandemic times. The report highlights positive practice and learning which we will continue to implement."

Royal College of Physicians. Caring for hospital patients with covid-19: quality of care in England examined by case record review. 2 August 2021. www.rcplondon.ac.uk/projects/outputs/caring-hospital-patients-covid-19.

This article is made freely available for use in accordance with BMJ's website terms and conditions for the duration of the covid-19 pandemic or until otherwise determined by BMJ. You may use, download and print the article for any lawful, non-commercial purpose (including text and data mining) provided that all copyright notices and trade marks are retained. 